\title{
Chediak-Higashi Sendromu: Olgu Sunumu
}

\section{Chediak-Higashi Syndrome: A Case Report}

\author{
Nuran Çetin* Sezin A. Akman* Serap Aksoylar* \\ Meral Türker* Ișll Çoker** \\ SSK Tepecik Eğitim Hastanesi, İzmir \\ * Çocuk Sağlığı ve Hastalıkları Klinikleri, ** Biyokimya Bölümü
}

\begin{abstract}
ÖZET
Chediak-Higashi Sendromu (CHS), tekrarlayan enfeksiyonlar, nörolojik bozukluklar, okulakutanöz albinizm, gümüs renginde saç ile karakterize, otozomal resesif kalıtllan genellikle fatal seyirli nadir bir hastalıktır. Akselere faz, olguların \%85'inde görülür. Ebstein-Barr Virus veya diğer lenfotropik viral enfeksiyonlar; ateş, yaygin lenfadenopati, hepatosplenomegali, pansitopeni ile karakterize olan bu fazl başlatabilir. Lökosit kemotaksisi ve NK hücrelerinin öldürme fonksiyonu azalmıştır. Kemik iliğinde, myelositer seri hücrelerinde dev sitoplazmik inklüzyon cisimciklerinin saptanmasi tanıy destekler. Chediak-Higashi Sendromunun spesifik bir tedavisi yoktur. Yüksek doz askorbik asit kullanımı klinik iyileşme sağlar. Akut enfeksiyonların tedavisinde antibiyotik uygulanır. Kemoterapi akselere fazda geçici iyileşme sağlayabilir. Allogenik kemik iliği transplantasyonu bazı hastalarda başarılı olmuştur. Olgumuzda, nistagmus, gümüş grisi saç rengi, periferik yayma ve kemik iliğinde myelositer seri hücrelerinde gözlenen dev intrasellüler granüllerin varlığı, hepatosplenomegali, pansitopeni CHS'nun akselere fazını düşundürmüştür. Fago-burst testinde \%22 aktivite saptanması azalmış bakterisidal aktivite lehine yorumlanmıstır. Nadir görülmesi nedeniyle sunulmuştur.
\end{abstract}

Analhtar Kelimeler: Chediak-Higashi sendromu, akselere faz

\section{SUMMARY}

Chediak-Higashi Syndrome (CHS) is a rare, usually fatal, autosomal recessive disease characterized by recurrent infections, oculocutaneous albinisms, progressif neurologic dysfunction. Accelerated phase occurs in $85 \%$ of the patients. Ebstein-Barr Virus or other lymphotropic viral infection may initiate this phase characterized by a lymphoma like picture with fever, generalized lymphadenopathy, hepatosplenomegaly, pancytopenia and sepsis. There is reduced activity of NK cells and dysfunction of leukocyte chemotaxis. Identification of giant cytoplasmic granules in the leukocytes and their precursors in the bone marrow may confirm the diagnosis. There is no spesific treatment for Chediak-Higashi Syndrome. High dose ascorbic acid has improved the clinical status. Antibiotics are valuable during acute infections. Chemotherapy can induce transient remission of the accelerated phase. Allogenic bone marrow transplantation has been found to be successful in some patients. Nistagmus, silver gray hair, giant intracellüler granules in myeloid cells, hepatosplenomegaly and pancytopenia implied the accelerated phase of $\mathrm{CHS}$ in our case. The determination of $22 \%$ of activity of phago-burst test was interpreted in favor of decreased bactericidal activity. It is reported because of its rarity.

Key Words: Chediak-Higashi syndrome, accelerated phase 
Chediak Higashi sendromu (CHS), tekrarlayan enfeksiyonlar, ilerleyici nörolojik fonksiyon bozukluğu, azalmış pigmentasyon ile karakterize, nadir görülen ve genellikle ilk 10 yaşta ölümle sonuçlanan bir immün yetmezlik hastalığıdır. Otozomal resesif kalıtılan hastalık, tekrarlayan bakteriyel enfeksiyonlar, parsiyel (okülokutanöz) albinizm, hepatosplenomegali ve nistagmus, hipotoni gibi nörolojik bulgularla seyredebilir. Periferik kanda lökositlerde ve kemik iliğindeki lökosit öncül hücrelerinde dev sitoplazmik granüler inklüzyonların görülmesi tanı koydurucudur $(1,2)$. Ateş, yaygın lenfadenopati, hepatosplenomegali, pansitopeni ile karakterize akselere faz, olguların \%85'inde görülür. Ebstein-Barr virus ve diğer lenfotropik viral enfeksiyonlar akselere fazı başlatabilir (3). ChediakHigashi hastalığında, nötrofil kemotaksisinde ve Natural Killer (NK) hücre aktivitesinde azalma, intrasellüler öldürme fonksiyonunda gecikme söz konusudur (4). Tedavide enfeksiyonlarla mücadeleyi içeren destek bakım yanında, askorbik asit, kolşisin, vinkristin ve steroid gibi kemoterapi programları ve splenektomi gibi yöntemler uygulanmaktadır $(5,6)$. Ancak kesin tedavi sağlayan tek yöntem allojenik kemik iliği transplantasyonudur (7). Prenatal tanı, amniotik sıvı ve koryonik villus hücrelerinde asit fosfataz $(+)$ hücreler, fetal kan örneğinde nötrofillerde dev granüllerin görülmesi ile mümkündür (8).

\section{OLGU}

3.5 aylik kız olgu (E.D., Prot. No 64669) solukluk, ateş yakınmaları ile yatırıldı. Özgeçmişinde miadında, normal spontan yolla, 3800 gr doğduğu, anne sütü ile beslendiği, gülümsemesinin zamanında olduğu, başını tutmaya henüz başladığı öğrenildi. Soygeçmişinde ebeveynler arasında uzak akrabalık tanımlandı. Altı aylik kız kardeşinin karaciğer ve dalak büyüklüğü olup kaybedildiği, sağ ve sağlıklı iki kız kardeşinin olduğu öğrenildi. Fizik incelemede ağırlığ1 6.100 gr (50 p), boy $62 \mathrm{~cm}$ (50 p), baş çevresi 40.5 $\mathrm{cm}(75 \mathrm{p})$, rektal $15137.8^{\circ} \mathrm{C}$, kardiyovasküler sistem ve solunum sistemi muayenesi olağan idi. Soluk görünümlü, saç rengi gümüşe yakın gri renkte olan olgunun horizontal nistagmusu mevcuttu. Karaciğer midklavikuler hatta $6-7 \mathrm{~cm}$, dalak 4-5 cm sert, keskin kenarl olarak ele geliyordu. Göz dibi bakısında optik disk sınırları silikti. Laboratuvar tetkiklerinde $\mathrm{Hb}: 6.3 \mathrm{gr} / \mathrm{dl}$, Htc: \%18.4, kırmızı küre sayısı: $2.140 .000 / \mathrm{mm}^{3}$, beyaz küre sayısı: $6.300 / \mathrm{mm}^{3}, \mathrm{MCV}: 86 \mathrm{fl}$, trombosit sayisı: $63.000 / \mathrm{mm}^{3}$, AST: $150 \mathrm{U} / \mathrm{L}$, ALT: 113 U/L, GGT: 162 U/L, LDH: 756 U/L, trigliserid: $415 \mathrm{mg} / \mathrm{dl}$, ferritin: $700.4 \mu \mathrm{g} / \mathrm{dl}$, fibrinojen $111 \mathrm{mg} / \mathrm{dl}$ olarak saptand. Periferik yaymada ve kemik iliği aspirasyonunda lenfomonositer seri ve myeloid seri hücrelerinde dev sitoplazmik granüller bulunan olgunun izleminde, persistan ateşi ve pansitopenisi gelişti. Aile öyküsü, gri saç rengi, nistagmus, kemik iliği aspirasyonunda myeloid seri hücrelerinde sitoplazmik granüller görülmesi nedeniyle ChediakHigashi sendromu düşünülen olgu, dirençli ateş, hepatosplenomegali, pansitopeni bulgularıla akselere faz olarak değerlendirildi. ELISA yöntemi ile bakilan hepatit, toxoplasma, EBV, CMV, HSV, rubella serolojilerinde akut enfeksiyon lehine bulgu saptanmadi. Immunglobulin düzeyleri normal bulunan olgunun lenfosit panelinde CD3: 67, CD19: 9, CD4: 31, CD8: 15, NK: 5, HLADR \%22 olarak saptand. Aktif T lenfosit hücrelerinde artma ve fago-burst testinde $\% 22$ aktivite belirlendi. Chediak-Higashi sendromuna yönelik olarak olguya $20 \mathrm{mg} / \mathrm{kg} /$ gün askorbik asit tedavisi başland. Tedavi seçenekleri ve kemik iliği translanplantasyonu konusunda bilgilendirilen aile bu tedavi biçimlerini kabul etmedi. Olgunun takibinde bir hafta sonra exitus olduğu öğrenildi.

\section{TARTISSMA}

Enfeksiyonlara yatkınlk, lökositlerde dev sitoplazmik granüller, okülokutanöz albinizmle seyreden Chediak-Higashi sendromu, herediter, fatal, bifazik bir hastalık olup oldukça nadir görülmektedir. Hastalığın ilk fazı, hayatın ilk 10 yilında ölümle sonuçlanan immun yetmezlik tablosunu, ikinci fazı ise, değişik dokuların histiositik infiltrasyonu ile giden lenfoproliferatif bulguları içerir (1). Klinik, patolojik, immunolojik bulgularla seyreden bu sendromda, beyaz kan hücrelerinde saptanan, değişik büyüklükteki intrasitoplazmik inklüzyon cisimcikleri 
karakteristiktir. Bu cisimcikler disfonksiyonel lizozomlar olarak da tanımlanmakta ve hastalığın, lizozomlarla ilgili genin mutasyonuna (kromozom 1q42-q43'de bulunan CHS geni) bağlı geliştiği düşünülmektedir (9). Olgumuzda, nistagmus, gümüş grisi saç rengi, periferik yayma ve kemik iliğinde miyelositer seri hücrelerinde gözlenen dev intrasellüler granüllerin varlığı, hepatosplenomegali, pansitopeni CHS'nun akselere fazını düşündürmüştür. Ebeveynler arasındaki akrabalık ve 6 aylikken kaybedilen kardeş öyküsü de otozomal resesif geçişli bu hastalık için tanıyı destekleyici bulgulardır. Fagoburst testinde \%22 aktivite saptanması azalmış bakterisidal aktivite lehine yorumlanmıștır. Nötrofillerde bakterisidal fonksiyonlarda bozulma, doğal öldürücü hücrelerin sitotoksik aktivitesinde azalma, defektif fagositoz ve/veya kemotaksis hastalığın, başlıca immunolojik parametrelerini oluşturmaktadır $(2,4)$. Ancak bakterisidal aktivitenin ve kemotaksisin normal olduğu olgular da bildirilmektedir (10). Chediak-Higashi Sendrom'lu olgularda nötrofil fonksiyon bozukluğu nedeni ile tekrarlayan solunum yolu, deri ve yumuşak doku enfeksiyonları sıktır. En sık enfeksiyon etkenleri Stafilokokkus aureus ve gram negatif basillerdir. Ancak enfeksiyon epizodları tanımlanmayan ve kutanöz melanozis dışında hiçbir klinik bulgusu olmayan, inklüzyon cisimciklerinin saptanması ile tanı alan olgular da bildirilmektedir (11). Olgumuzun özgeçmişinde, tekrarlayan ciddi enfeksiyon öyküsünün olmaması, yaşının küçüklüğüne bağlanabilir. Literatürde bazı olgularda EBV-VCA (viral kapsid antijen) ve EBNA (nükleer antijen) titrelerinin yüksek saptanması akselere fazın EBV enfeksiyonu ile ilgisinin tartışılmasına yol açmıştır $(3,12)$. EBV ve diğer viral belirleyiciler hastada negatif bulunmuştur. Benzer klinik tablo ile seyreden Griscelli Sendromundan dev sitoplazmik granüllerin görülmesi ile ayırt edilmiştir (13). ChediakHigashi Sendromu'nun akselere fazı hemofagositik lenfohistiositoz kliniği göstermektedir; bu nedenle lenfohistiositozların tanısında CHS de akla getirilmelidir (14).

Akraba evliliklerinin yoğun olduğu ülkemizde, otozomal resesif kalitilan hastaliklar hala öne- mini sürdürmeye devam etmektedir. Ateş, hepatosplenomegali, albinism ve pansitopeni bulunan olgularda Chediak-Higashi Sendromu da düşünülmelidir.

\section{KAYNAILAR}

1. Von Moers A, Van Landegheu FK, Cohn RD, Baumgarten E, Bürgen J, Stoltenburg-Didinger G. Dystrophinopathy in a boy with Chediak-Higashi syndrome. Neuromuscul Disord 1998;8:489-94.

2. Carnide EM, Jacob CM, Pastorino AC, Bellinati Pires R, Costa MB, Grumach AS. Chediak-Higashi syndrome: Presentation of seven cases. Rev Paul Med 1998;116:1873-8.

3. Kinugawa N. Ebstein Barr virus infection in Chediak Higashi syndrome mimicking acute lymphocytic leukemia. Am J Pediatr Hematol Oncol 1990;12:182-6.

4. Bellinati-Pires R, Salgado MM, Joazeiro PP, CarneiroSampaio MM. Delayed phagocytosis and bacterial killing in Chediak-Higashi syndrome neutrophils detected by a fluorochrome assay. Ultrastructural aspects. Mem Inst Oswaldo Cruz 1992;87:575-81.

5. Harfi HA, Malik SA. Chediak-Higashi syndrome: Clinical, hematologic and immunologic improvement after splenoctomy. Ann Allergy 1992;69:147-50.

6. Saitah H, Komiyama A, Norose N, Morosawa $\mathrm{H}$, Akabane T. Development of the accelerated phase during ascorbic acid therapy in Chediak-Higashi syndrome and efficacy of colchicine on its management. Br J Haematol 1981;48:79-84.

7. Haddad E, Le Deist F, Blanche S, Benkerrou M, Rohrlich P, Vilmer E, et al. Treatment of ChediakHigashi syndrome by allogenic bone marrow transplantation: Report of 10 cases. Blood 1995; 85: 3328-33.

8. Diukman R, Tanigawara S, Cowan MS, Golbus MS. Prenatal diagnosis of Chediak-Higashi syndrome. Prenat Diagn 1992;12:877-85.

9. Introne W, Boissy RE, Gahl WA. Clinical, molecular, and cell biological aspects of Chediak-Higashi syndrome. Mol Genet Metab 1999;68:283-303.

10. Gale PF, Parkin JL, Quie PG, Pettil RE, Nelson RP, Brunning RD. Leukocyte granulation abnormality associated with normal neutrophil function and neurologic impairment. Ann J Clin Pathol 1986;86:33- 49.

11. Yasha TS, Vani S, Vasanth A, Augustus M, Ramamohan Y, Das S, et al. Chediak-Higashi syndrome a case report with ultrastructural and cytogenetic study. Indian J Pathol Microbiol 1997;40: 75-9.

12. Merino F, Klein GO, Henle W, Raminez-Duque P, Forsgren M, Amesty C. Elevated antibody titers to Ebstein - Barr virus and low natural killer cell activity 
Çetin ve ark.

in patients with Chediak-Higashi syndrome. Clin Immunol Immunopathol 1983;27:326-39.

13. Sanal O, Küçükali T, Ersoy F, Tinaztepe K, Gögüs S. Griscelli' syndrome: clinical features of three siblings. Turk J Pediatr 1993;35:115-9.

14. Favara BE. Hemophagocytic lymphohistiocytosis: A hemophagocytic syndrome. Semin Diagn Pathol 1992;9:63-74.

\section{Yazışma adresi:}

Dr. Nuran ÇETIN

Yüzbaşı İbrahim Hakkı Cad. Ersoy Apt. No: 193

Bornova, İzmir

Tel: 02323425325 